\title{
PENERAPAN PRINSIP SYARIAH PADA LEMBAGA KEUANGAN SYARIAH
}

\author{
Arief Budiono \\ Universitas Muhammadiyah Ponorogo \\ Email: areevahims@gmail.com
}

\begin{abstract}
Abstrak
L embaga Keuangan Syariah (LKS) saat ini telah ada dan berkembang dengan cukup pesat. Telah banyak varian dari LKS diseluruh Indonesia dan termasuk pula adalah Bank Syariah. LKS merupakan lembaga keuangan yang beroperasional dan berjalan dengan prinsip syariah Islam. Prinsip syariah Islam ini berbeda dari perbankan atau lembaga keuangan konvensional. LKS sebagai lembaga keuangan dengan prinsip syariah awalnya hadir sebagai pilihan sekaligus solusi untuk muslim yang ingin terhindar dari praktek bank atau lembaga keuangan konvensional yang menggunakan system ribawi namun akhirnya juga dapat menjadi pilihan bagi selain umat muslim. Penyelenggaraan LKS berarti wajib bertanggung jawab secara syariah untuk menjaga tidak hanya agar praktek dalam LKS itu bebas riba saja tapi juga harus bebas dari unsur unsur maysir/ judi dan Ghoror/spekulasi/judi. Islam memerintahkan untuk menjauhi hal hal tersebut karena hal tersebut dianggap sebagai berbuat zhalim atau kerusakan Penyelenggara LKS dituntut memiliki tidak hanya visi bisnis an sich yang bertujuan mengeruk laba yang setinggi tingginya dengan mengesampingkan syariah namun juga harus memiliki visi syariah. Proses agar LKS tentap berada dalam prinsip prinsip syariah ketika beroperasional menjadi tanggung jawab bersama antara lain pengelola LKS dan institusi negara yang ditunjuk untuk melakukan proses dan prosedur agar LKS tetap dalam koridor yang seharusnya dan tidak melakukan hilah/trik hanya sekedar kamuflase berkedok syariah dalam parktek dan operasionalnya
\end{abstract}

Kata Kunci: Prinsip, Lembaga Keuangan, Syariah

Abstract
hariah financial institution nowadays has been grown fast. There have
been many facilities provided by Shariah Financial Institutions in
Indonesia including Shariah Banking. Shariah Financial Institutions are
financial institutions that operate and run based on Islamic shariah principles.
This Islamic shariah principle is different from general banking or conventional
financial institution. Shariah Financial Institutions, as financial institution with
shariah principle, becomes an option and solution for Muslim only who want
to avoid from banking system or conventional financial institutions that utilize
usurious system but finally these shariah financial institutions can be for all
people. The Shariah Financial Institution management should be responsible
with shariah principle to commit the system not only free from usurious system
but also free from gambling and speculation system. Islam regulates to avoid
those systems because those systems are considered as immoral behavior. The
Shariah Financial Institution management is required to not only have high
profitable business vision but also have shariah vision. It is the manager of
shariah financial institution and governmental institution's responsibility to


commit the process based on shariah principles. These managers are pointed to do the process and procedures appropriately to keep the shariah financial institutions in the right track and not do profitable system that is under shariah system in its practice and operational system.

\section{Keywords: principle, financial institution, shariah}

\section{PENDAHULUAN}

\section{Latar belakang Masalah}

Seorang muslim di tuntut untuk hidup dalam bingkai dan koridor ketaatan kepada Allah Ta'ala dimana seorang muslim dalam ajaran agama Islam di larang atau diharamkan untuk memakan harta secara bathil (tidak benar), diantara bentuk memakan harta secara bathil adalah dengan cara mengambil riba atau bertransaksi dengan metode yang ribawi. Didalam Al Qur'an surah Ali Imran ayat 130 diterangkan bahwa "Hai orang-orang yang beriman, janganlah kamu memakan riba dengan berlipat ganda dan bertakwalah kamu kepada Allah supaya kamu mendapat keberuntungan."

Ayat diatas adalah sebuah perintah tetapi perintahnya adalah untuk meninggalkan (perintah yang melarang melakukan sesuatu), Di dalam Ushul fiqh larangan terhadap sesuatu adalah perintah untuk berhenti mengerjakan sesuatu tersebut. Dalam hal ini larangan memakan riba berarti perintah untuk berhenti mengerjakan riba. Hukum asal larangan adalah pengharaman (Mohammed Hudribiq, 1988:199). Di dalam bahasa Arab, bahwa lafadz "Riba" itu bisa mengandung makna tambahan secara mutlaq atau bahwa Riba secara bahasa bermakna : Ziyadah / tambahan. Dalam pengertian lain secara linguistik, riba juga berarti Tumbuh dam membesar. Adapun menurut istilah teknis, riba berarti pengambilan tambahan dari harta pokok atau modal secara batil (Muhammad Syafii Antoni, 2009:37)

Bagi seorang muslim riba secara keseluruhannya adalah haram, baik riba yang berlipat ganda maupun yang sedikit dan riba merupakan perbuatan yang tercela karena merupakan perbuatan yang mengeksploitasi sesama manusia. Perbuatan riba tidaklah ada perbedaan apakah dilakukan oleh pribadi maupun berjamaah secara institusi dimana semuanya sama saja keharamannnya bagi muslim. Meskipun masih ada sementara pendapat khususnya di Indonesia yang masih meragukan apakah bunga bank termasuk riba atau bukan, maka sesungguhnya telah menjadi kesepakatan ulama, ahli fikih dan Islamic banker dikalangan dunia (Achmad Baraba, 2010:3)

Sebagai negara dengan pemeluk agama Islam terbanyak di dunia maka menjadi keniscayaan dan kepastian bahwa cukup banyak muslim yang merasa keberatan harus bertransaksi atau berurusan dengan lembaga perbankan yang menerapkan system riba. Masyarakat muslim yang enggan berurusan dengan perbankan karena takut riba biasanya menggunakan perbankan hanya sebagai lalu lintas dana seperti mentranfer uang atau transaksi lain yang hanya dapat dilakukan perbankan dan sesegera mungkin menarik dana dari perbankan setelah mendapatkan tranferan dana atau kebutuhannya terpenuhi.

Berdasarkan hasil penelitian Bank Indonesia tentang potensi dan preferensi bank syariah di Jawa Barat, Jawa Tengah dan Jawa Timur pada tahun 1999 membuktikan masih terdapat masyarakat yang enggan berhubungan dengan bank sebagai akibat dari diterapkannya sistem bunga yang diyakini sebagai riba yang diharamkan. Oleh karena itu dibutuhkan suatu konsep alternatif sistem perbankan yang dapat menampung tuntutan dan kebutuhan masyarakat, dengan sistim bagi hasil dan resiko (profit and loss sharing), yang mengedepankan prinsip keadilan dan kebersamaan dalam berusaha, baik dalam memperoleh keuntungan maupun dalam menghadapi resiko.

Atas inisiatif dari beberapa pihak dari kalangan umat muslim yang diprakarsai Majelis Ulama Indonesia (MUI) didirikanlah bank dengan konsep syariah pertama yaitu Bank Muamalat Indonesia yang berdiri pada tanggal 1 November 1991 dengan tujuan memberikan solusi bagi umat muslim 
untuk tetap dapat terhindar dari praktik ribawi. Pendirian syariah pertama ini kemudian direspon positif oleh pemerintah yang mendukungnya dengan ditelurkannya undang undang nomor 7 tahun 1992 yang mengakomodasi prinsip syariah dalam pelaksanaan praktik perbankan.

Bank Muamalat Indonesia inilah yang merupakan bank umum Islam pertama yang menerapkan system bagi hasil di Indonesia yang berbeda dengan sistem perbankan yang selama di kenal oleh masyarakat Indonesia. Hadirnya BMI ini merupakan jawaban tersendiri bagi umat Islam yang menginginkan transaksi yang bebas riba yang ada di bank konvensional, keberadaan bank syariah dirasakan terlambat dibandingkan dengan bank bank Islam lainnya di negara negara lainnya seperti Malaysia, Pakistan dan negara negara teluk lainnya.

Sudah cukup lama ummat Islam Indonesia, dan belahan dunia lainnya, menginginkan perekonomian yang berbasis pada nilai-nilai dan Prinsip Syari'ah untuk dapat diterapkan dalam segala aspek kehidupan dan dalam transaksi antar ummat yang didasarkan pada aturan-aturan Syari'ah. Keinginan ini didasari oleh kesadaran untuk menerapkan Islam secara utuh dalam segala aspek kehidupan, sebagaimana dijelaskan dalam surah Al-Baqarah ayat (208) yang artinya sebagai berikut: "Hai orang-orang yang beriman, masukklah kamu kedalam Islam secara kaffah (utuh/ menyeluruh)" secara kaffah bukan secara parsial. Islam tidak hanya diwujudkan dalam bentuk ritualisme ibadah semata, dan dimarginalkan dari dunia politik, ekonomi, perbankan, asuransi, pasar modal, pembiayaan proyek, transaksi ekspor-impor dan lain-lain, apabila hal ini terjadi, maka ummat Islam telah menjauhkan Islam dari kehidupannya.

Undang-undang No. 10 Tahun 1998 tentang Penyempurnaan Undang-undang No.7 Tahun 1992 tentang Perbankan merupakan langkah maju dalam perkembangan perbankan, terutama bagi perbankan syariah. Dalam undang-undang ini perbankan syariah diberikan perlakuan yang sama equal treatment dengan perbankan konvensional. Padahal jika dilihat jumlahnya, ketika undangundang itu disahkan, baru ada satu bank syariah -Bank Muamalat- dan sekitar 70 BPR Syariah.

Disahkannya Undang-undang No. 10 Tahun 1998 telah membuka kesempatan lebih luas bagi bank syariah untuk berkembang. Undang-undang ini bahkan tidak saja menyebut bank syariah secara berdampingan dengan bank konvensional dalam pasal demi pasal, tetapi juga menyatakan secara rinci prinsip produk perbankan syariah, seperti Murabahah, Salam, Istisna, Mudharabah, Musyarakah dan Ijarah; padahal dalam Undang-undang No. 7 Tahun 1992 tetang Perbankan, nama syariah pun sama sekali tidak disebut (Cecep Maskanul Hakim, 2013:1).

Perbankan Syariah maupun lembaga keuangan syariah semakin semarak dengan adanya dukungan terhadap pengembangan perbankan syariah juga diperlihatkan dengan adanya "dual banking system", dimana bank konvensional diperkenankan untuk membuka unit usaha syariah (HarifAmali Rivai, 2006:2). Sistem perbankkan Syariah sesungguhnya tidak terbatas pasarnya pada nasabah yang memiliki ikatan emosional keagamaan (masyarakat muslim). Layanan perbankan syariah dapat dinikmati oleh siapa saja, tidak tergantung agama yang dianut, sepanjang bersedia mengikuti cara berbisnis yang diperbolehkan secara syariah. Masyarakat membutuhkan lembaga keuangan yang kuat, transparan, adil dan berkomitmen membantu meningkatkan perekonomian dan usaha nasabah (Lina Maulidiana.. 2011: 72).

Kesemarakan dan begitu banyaknya Bank syariah, Lembaga Keuangan Syariah maupun perbankan yang menganut dual banking system dalam artian bahwa perbankan konvensional yang membuka unit syariah dengan sendirinya memerlukan pengawasan yang mendalam dan cermat dalam berbagai aspek operasionalnya. Perbankan syariah dan lembaga keuangan syariah (LKS) didirikan dengan prinsip utama adalah sesuai dengan syariah Islam yang tidak mengembangkan Produk Ribawi guna mengakomodasi umat muslim yang enggan berurusan dengan riba atau anggota masyarakat secara umum yang ingin bertransaksi dengan sistem syariah. Perbankan syariah tidak didirikan dengan hanya niat untuk sebagai tampilan saja untuk menarik dana masyarakat tetapi dijalankan dengan praktik lembaga keuangan konvensional dan inilah esensi dari pengawasan agar Lembaga Keuangan syariah tetap beroperasi sesuai dengan prinsip prinsip syariah.

Paradigma yang harus dipegang dalam pengembangan produk lembaga keuangan syariah 
adalah bahwa berbeda dengan yang ada dalam bank atau lembaga keuangan konvensional, yang memakai jenis transaksi yaitu pinjaman berinterest (riba), dalam lembaga keuangan syariah produk-produk harus dikembangkan mengikuti karakter dan sifat produk syariah yang berbeda satu sama lain. Resiko dan jangka waktu merupakan faktor kedua sesudah karakter dan sifat itu diletakkan.

Misalnya, karakter produk Murabahah adalah jual beli barang. Lembaga keuangan syariah bertindak sebagai penjual dan nasabah sebagai pembeli. Lembaga keuangan syariah boleh meminta jaminan tambahan selain barang yang dibeli. Ketika produk ini diterapkan pada pembiayaan konstruksi, tentu tidak tepat karena harus ada barang yang diperjualbelikan, bukan proyek yang bentuknya tidak nyata. Jika dicocokkan dengan menjual beli bahan konstruksi seperti batu, pasir, semen dan lain-lain, bank akan mendapat kesulitan dalam perincian barang. Kalau memaksa, ada sesuatu yang tidak bisa diperjual belikan, seperti tenaga kerja dan harus digunakan produk lain yaitu Ijarah (sewa).

Artinya Murabahah tidak cocok untuk pembiayaan konstruksi. Ada yang lebih cocok, misalnya Istisna, yaitu produk Syariah lain untuk jual beli, dimana bank bertindak sebagai pembeli barang yang akan dibangun/ dibuat. Lembaga keuangan syariah membayar secara bertahap kepada kontraktor dan setelah selesai bank menjualnya kepada debitur.

Pengawasan atas pelaksanaan prinsip prinsip syariah pada lembaga keuangan syariah menjadi sesuatu yang sangat urgen dan utama untuk dilaksanakan dimana hal itu merupakan core atau initi dari operasional lembaga keuangan syariah. Pengawasan juga diperlukan untuk menemukan praktik praktik fraud atau kecurangan yang dilakukan oleh oknum oknum lembaga keuangan syariah demi keuntungan semata dan untuk melindungi nasabah atau para pihak yang bertransaksi atau melakukan transaksi dengan lembaga keuangan syariah.

Lembaga Keuangan Syariah (LKS) tidak hanya dituntut bertanggung jawab tentang kuantitas perhitungan angka laba karena selain laba adapula keyakinan bahwa ia kelak bertanggung-jawab kepada Allah dalam menjalankan LKS. LKS harus konsisten untuk melakukan tanggung jawab terhadap penerapan prinsip syariah. LKS hidup di tengah-tengah masyarakat dengan mengusung platform syariah.

Tulisan dalam paper ini menelaah dan menganalisa tentang penerapan pirnsip syariah oleh LKS. Penerapan prinssip tersebut sebagai bentuk pemenuhan tanggung jawab syariah ditinjau dari hukum Islam sekaligus mencoba menganalisis dengan realita.

\section{Rumusan Masalah}

Dari uraian di atas, maka terdapat rumusan masalah sebagai berikut:

a. Mengapa penerapan prinsip syariah oleh LKS menjadi permasalahan yang urgent?

b. Bagaimanakah kondisi penerapan prinsip syariah oleh LKS?

\section{HASIL DAN PEMBAHASAN}

\section{Urgensi penerapan prinsip syariah oleh LKS menjadi permasalahan yang urgent.}

LKS dengan prinsip syariah merupakan alternatif positif bagi sebagian masyarakat karena prinsip agama atau kepercayaan tidak bersedia memanfaatkan jasa-jasa bankatau lembaga konvensional yang memiliki prinsip sistem bunga yang dianggap merupakan pelanggaran terhadap syariah agama Islam karena tidak sesuai dengan konsep Islam yaitu perjanjian/akad yang tidak mengandung gharar (ketidak jelasan), maisir (perjudian) dan riba (bunga uang). Namun demikian, apakah penerapan prinsip syariah pada LKS telah sesuai dengan syariah?

LKS dalam melaksanakan transaksi muamalah dibangun atas asas maslahat. Hukum Islam tidak melarang bentuk transaksi kecuali terdapat unsur kezaliman di dalamnya, seperti riba, penimbunan (ihtikâr ), penipuan dan lainnya, atau diindikasikan transaksi tersebut dapat menimbulkan perselisihan atau permusuhan di antara manusia, seperti adanya gharar atau bersifat spekulasi. Permasalahan pokok dalam muamalah adalah unsur kemaslahatan. Jika 
terdapat maslahah, maka sangat dimungkinkan transaksi tersebut diperbolehkan. Seperti halnya diperbolehkannya akad istishna, padahal ia merupakan jual beli/bai ' al-ma'dûm (obyek tidak ada saat akad), karena adanya kebutuhan dan maslahah yang akan didapatkan, tidak menimbulkan perselisihan dan sudah menjadi kebiasaan masyarakat.

Sebagai LKS sebenarnya system yang diperlakukan harus sesuai dengan syariah. Transaksi dan praktek keuangan di LKS/bank syariah sebenarnya tidak boleh dimaksudkan untuk hanya sekedar hîlah atau trik untuk menghalalkan praktik riba, Maisir dan ghurur. Tujuan sebagai LKS tidak boleh hanya memiliki maksud dan tujuan untuk mendapatkan uang tunai belaka sebagai laba, walaupun kedatangan nasabah ke LKS/bank syariah sebenarnya adalah untuk mendapatkan uang tunai untuk keperluannya.

Terdapat sementara itu praktik pihak LKS/bank syariah melaksanakan praktek tidak membeli barang melainkan hanya memberikan uang tunai saja dengan akad seolah olah bahwa uang itu akan di belikan barang sesuai yang diajukan debitur dan setelah uang diserahkan tidak ada control apakah sudah dibelikan sesuai pengajuan ataukah tidak. Ini bermakna bahwa LKS tidak hendak menjualnya kepada nasabah tapi hanya melakukan Hilah atau pengelabuhan seolah olah adalah sesuai syariah padahal merupakan sesuatu yang mengandung riba, sehingga dapat dimaknai bahwa LKS/bank syariah sebenarnya tidak sungguh-sungguh menerapkan prinsip syariah yang seharusnya menjadi pedoman operasionalnya

Salah satu hal yang merupakan tulang punggung dari LKS adalahs system Loss and Profit Sharing (LPS) Sistem bagi hasil dalam akad musyarakah dan mudharabah pada awalnya dianggap sebagai tulang punggung operasi LKS, namun dalam prakteknya, jenis pembiayaan bagi hasil ini hanya merupakan bagian kecil yang diberikan LKS di Indonesia bahkan di dunia. Data menunjukan bahwa di FFI Turki, pembiayaan bagi hasil hanya 0,7 \% dari total Kredit per 1993, Bank Islam Malaysia hanya 1,9\% per 1994, FIB Bahrain hanya 7,6\% per 1993, Bank Islam Bangladesh 3,2\%, Dubai 3,7\%, Yordania Islamic Bank hanya 2,8\%. (Nasyitotul Jannah, 2012:4)

Sejak awal,LKS dirancang sebagai intermediasi antara pemilik dana dengan yang membutuhkan dana, agar terjadi interaksi dan sinergi ekonomis antara keduanya yang saling menguntungkan. Oleh karena itu system bagi hasil/profit and loss sharing (PLS) merupakan alat terbaik untuk menjembatani kepentingan kedua belah pihak, tentu saja dengan tetap mendasarkannya pada nilai-nilai empati dan humanisme. Namun ternyata ketika dilakukan dalam bentuk pembiayaan institusional LKS, system PLS ini memiliki beberapa hambatan, yang karenanya LKS enggan menempatkan sebagian besar porfolio asetnya dalam pembiayaan PLS ini.

Resiko dalam system PLS ini paling serius disebabkan karena masyarakat pada umumnya banyak yang mengabaikan norma dan akhlak Islam dalam transaksi ekonominya dan dihinggapi mental diverse selection (seleksi yang merugikan) dan moral hazard. Artinya seorang nasabah yang memiliki usaha dengan ekspektasi laba yang rendah sangat mungkin memilih dana ekuitas dari lembaga keuangan Islam dengan akad mudharabah dan musyarakah, sementara jika ia punya ekspektasi laba yang sangat tinggi maka ia akan memilih pinjaman berbunga tetap dari lembaga keuangan konvensional dikarenakan angka sharing hasil yang cukup tinggi dibandingkan dari interest bank konvensional.

Kendala lain, dalam sistem bagi hasil ini, LKS dituntut menerapkan monitoring yang intensif kepada para nasabah sehingga dengan demikian skema bagi hasil bisa dijalankan dengan baik. Dilain pihak, LKS sementara ini belum memungkinkan untuk sepenuhnya mengembangkan sebuah system perjanjian yang memfasilitasi kemitraan ekuitas antara LKS dan nasabah seraya tetap memonitor biaya pada tingkat yang cukup layak dan menghilangkan problem moral hazard yang muncul ketika ada informasi tidak simetris antara LKS dan nasabah tentang laba usaha.

Adanya pengawasan yang intensif LKS kepada mitranya menyebabkan timbulnya opini bahwa standar moral yang berkembang dan diantu di komunitas muslim tidak memberi kebebasan penggunaan bagi hasil sebagai mekanisme investasi. Pengawasan yang intensif tidak seharusnya dipahami sebagai tali kekang tetapi sebagai bantuan dari LKS untuk debiturnya dalam 
mengembangkan usahanya karena bagaimanapun dengan system PLS ini apabila debitur bangkrut atau rugi maka LKS juga turut merasakan kerugian tersebut.

Manurut Handbook of Islami Banking diterbitkan dalam bahasa Arab oleh The International Association of Islamic Banks di Kairo sebagaimana yang dikutip Sutan Remi Sjahdeni,peran LKS ialah menyediakan fasilitas dengan cara mengupayakan instrumen-instrumen yang sesuai dengan ketentuan dan prinsip syariah (Adiwarman A Karim, 2004:2). Upaya tersebut juga terkendala oleh Regulasi perbankan yang berlaku belum sepenuhnya mengakomodir operasional LKS, mengingat adanya sejumlah perbedaan dalam pelaksanaan operasional LKS dengan lembaga keuangan konvensional.

Dalam hal pertumbuhan dan perkembangan ekonomi syariah dunia yang begitu pesat, aplikasi syariah dalam konteks ke-Indonesia-an justru acap kali mengahadapi ganjalan yang berasal dari bangsa sendiri. Bahkan menurut Prof. Abdul Manan, belum sepenuhnya peraturan pemerintah di bidang perbankan syariah yang memadai sekaligus solusi untuk menjawab permasalahan pengembangan LKS dan bank syariah, upaya merealisasikan undang undang yang lebih komprehensif belum begitu memadai, agar mampu menginterprestasikan perkembangan bank syariah di masa depan yang membutuhkan proses perbankan secara bertahap (Abdul Manan, 2012:32).

Regulasi perbankan yang ada kiranya masih perlu disesuaikan agar memenuhi ketentuan syariah agar dapat beroperasi secara relatif dan efisien serta mampu bersaing, antara lain; pertama, instrument yang diperlukan untuk mengatasi masalah likuiditas; kedua, instrumen moneter yang sesuai dengan prinsip syariah untuk keperluan pelaksanaan tugas LKS; ketiga, standarisasi akuntansi, audit dan sistem pelaporan; keempat, regulasi yang mengatur mengenai prinsip kehatihatian. Ketentuan keempat regulasi ini diperlukan agar LKS dapat menjadi elemen terpenting dari system keuangan.

Demikian juga yang sangat penting adalah masalah regulasi, penerapan syariah yang makin meluas dari industri keuangan dan permodalan membutuhkan regulasi yang tidak saling bertentangan atau tumpang tindih dengan aturan sistem ekonomi konvensional. Para pelaku ekonomi syariah sangat mengharapkan regulasi untuk perbankan syariah bisa memudahkan mereka untuk berekspansi bukan malah membatasi. Realitas di lapangan menunjukan, para pelaku ekonomi syariah masih menghadapi tantangan berat untuk menanamkan prinsip syariah sehingga mengakar kuat dalam perekonomian nasional dan umat Islam sendiri. Berkaitan dengan hal tersebut penerapan ekonomi syariah harus dipahami sebagai bagian integral dari penerapan syariat secara kaffah.

Keyakinan kita untuk penerapan hukum syariah dalam perekonomian telah didukung oleh penerapan hukum syariah di bidang yang lain seperti penyelesaian sengketa ekonomi syariah yang telah tegas dalam penyelsaiannya sebagaimana Pasal 55 ayat 2 UU Nomor 21 Tahun 2008 Tentang Perbankan Syariah telah dibatalkan oleh Mahkamah Konstitusi melalui putusan Nomor: 93/PUU-X/2012 mengakhiri dualisme (choice of forum) penyelesaian sengketa ekonomi syariah antara peradilan agama dan peradilan umum. Teori dan sistem ekonomi syariah yang baik, tentu harus mengakhiri atas keraguan penyelesaian sengketa (Fokus Media, 2011: 63).

Perbankan Syariah dalam melakukan kegiatan usahanya berasaskan Prinsip Syariah, demokrasi ekonomi, dan prinsip kehati hatian. Prinsip Syariah adalah prinsip hukum Islam dalam kegiatan perbankan berdasarkan fatwa yang dikeluarkan oleh Majelis Ulama Indonesia, dalam hal ini adalah Dewan Syariah Nasional (DSN MUI), yang untuk selanjutnya fatwa tersebut dituangkan dalam Peraturan Bank Indonesia.

Mengenai masalah kepatuhan syariah (syariah compliance), kewenangannya berada pada Majelis Ulama Indonesia (MUI), direpresentasikan melalui Dewan Pengawas Syariah (DPS) yang harus dibentuk pada masing-masing Bank Syariah dan LKS. Dewan Pengawas Syariah bertugas memberi nasihat dan saran kepada direksi agar kegiatan tetap berada dalam koridor syariah) 
Perkembangan industri keuangan syari'ah khususnya sektor perbankan di negara Indonesia tentunya membutuhkan sistem tata kelola yang menjamin tercapainya tujuan-tujuan LKS. Sistem tata kelola lembaga keuangan syari'ah tentunya memiliki pendekatan yang berbeda dengan sistem tata kelola perbankan umumnya. Hal ini disebabkan adanya keharusan bagi lembaga keuangan syari'ah untuk memastikan terlaksananya prinsip-prinsip syari'ah pada seluruh produk, instrumen, operasi, praktek dan manajemen perbankan syari'ah. Oleh karenya, perbankan syari'ah membutuhkan sistem tata kelola yang dapat memastikan kepatuhan terhadap syari'ah (Ali Rama, 2015: 3)

Sistem tata keloa yang dimaksud adalah sistem tata kelola syari'ah atau biasa disebut dengan istilah shariah goveranance (SG) bagi lembaga keuangan syari'ah. SG menurut Isra memiliki kesamaan dengan konsep hisbah dalam sejarah. Dengan demikian sistem tata kelola syari'ah merupakan sistem tata kelola yang unik yang hanya ada pada lembaga keuangan syari'ah. Salah satu elemen penting dari sistem tersebut adalah keberadaan dewan syari'ah sebagai bagian struktur organisasi perusahaan (Isra, 2010:106).

Lembaga keuangan yang menawarkan produk dan layanan syari'ah tentu harus memiliki sistem tata kelola yang dapat memastikan prinsip syari'ah diterapkan dalam keseluruhan perusahaan. Istilah tata kelola syari'ah atau shariah governance dimunculkan oleh lembaga berstandar internasional seperti AAOIFI (Accounting and Auditing Organization for Islamic Financial Institutions) dan IFSB (Islamic Financial Services Board) sebagai bentuk sistem tata kelola bagi lembaga keuangan syari'ah.

Tata kelola syari' ah menurut IFSB ialah "Seperangkat pengaturan kelembagaan dan organisasi dimana lembaga keuangan syari'ah dapat memastikan bahwa terdapat pandangan independen tentang kepatuhan syari'ah melalui proses penerbitan fatwa syari'ah yang relevan, penyebaran informasi fatwa dan review internal kepatuhan syari'ah. Definisi tersebut memiliki 3 (tiga) komponen utama, yaitu (1) struktur organisasi perusahaan terdapat Dewan Pengawas Syari'ah dan fungsi yang koheren seperti Divisi Syari'ah dan Internal Audit; (2) pendapat atau opini yang bersifat independen tentang pemenuhan terhadap syari'ah; dan (3) proses review terhadap pemenuhan syari'ah (IFSB, 2009:138) .

Sangat penting untuk memastikan semua aktivitas, transaksi dan operasi LKS mematuhi prinsip-prinsip syari'ah dan moral Islam. Dewan Pengawas Syari'ah sebagai elemen penting dari shariah governance menjadi lembaga ideal yang dapat menjalankan fungsi muhtasib sebagai institusi internal dari sistem hisbah dalam konteks LKS modern. ruang lingkup kerangka shariah governance meliputi aspek exante dan ex-post kepatuhan syari'ah. Ex-ante merujuk kepada proses penerbitan fatwa dan penyebarannya. Sementara ex-post merujuk kepada proses review sharia internal secara periodik dan tahunan. Adapun proses ex-ante melalui tahapan pengajuan proposal produk, dokumentasi hukum, review syari'ah dan penyebaran fatwa. Sementara proses ex-post terdiri dari review syari'ah secara berkala dan tahunan (Ali Rama, 2014: 8).

Hassan dkk (2013) dengan membagi aspek tata kelola syari'ah menjadi 4 (empat) aspek utama, yaitu regulasi, struktur organisasi, proses dan fungsi dewan pengawas syari'ah. Adapun kerangka regulasi tata kelola syari'ah tersebut dapat dijabarkan (Hassan, Dkk).

Aspek regulasi berusaha untuk melihat bagaimana kerangka hukum pengaturan sistem tata kelola syari'ah. Apakah diatur dalam bentuk undang-undang tersendiri yang terpisah dari konvensional dan juga apakah diatur dalam bentuk peraturan dan guideline.

Sistem tata kelola syari'ah diatur dalam UU No. 21 Tahun 2008 tentang Perbankan Syari'ah. Konsep teknis dan operasionalnya selanjutnya dijabarkan dalam bentuk Peraturan Bank Indonesia (PBI) dan Surat Edaran Bank Indonesia (SEBI). Sistem tata kelola syari'ah diatur dalam bentuk undang-undang dan guideline yang dikeluarkan.

Di Indonesia, sistem tata kelola syari'ah berdasarkan UU No. 21/2008 menempatkan DPS (Dewan Pengawas Syari'ah) sebagai pihak penting dalam pengawasan kepatuhan prinsip-prinsip 
syari'ah di internal perbankan syari'ah. DPS bertugas memberikan nasehat dan saran kepada direksi serta mengawasi kegiatan LKS agar sesuai dengan prinsip syari'ah.

Selanjutnya pada level nasional, ada lembaga bernama Dewan Syari'ah Nasional (DSN) yang dibentuk oleh Majelis Ulama Indonesia (MUI) yang bertugas dan memiliki kewenangan untuk menetapkan fatwa tentang produk dan jasa dalam kegiatan usaha bank yang melaksanakan kegiatan usaha berdasarkan prinsip syari'ah. Dengan demikian, DPS adalah perpanjangan tangan dari DSN untuk melakukan pengawasan atas kesesuaian kegiatan operasional terhadap fatwa yang dikeluarkan oleh DSN. Meskipun UU Perbankan Syari'ah tidak memberikan penjelasan yang rinci namun dijelaskan lewat PBI ini secara umum menjelaskan tentang konsep GCG serta bagaimana peran masing-masing dari Dewan Komisaris, Direksi, Komite-Komite, dan Dewan Pengawas Syari'ah. Dalam PBI ini juga dijelaskan tentang format self assessment pelaksanaan GCG pada bank syari'ah.

Pada bagian pengawasan syari'ah dijelaskan tentang mekanisme pengangkatan anggota DPS, masa jabatan, tugas dan tanggung jawab, mekanisme pelaporan hasil pengawasan DPS dan sanksi bagi DPS yang tidak melaksanakan kewajibannya Meskipun guidelines ini cukup menyeluruh tapi belum bisa disebut sebagai model kerangka SG yang menyeluruh bagi LKS. Format guidelines GCG ini cenderung hasil penyesuaian dengan guidelines GCG bagi bank dan lembaga keuangan konvensional yang sudah dikeluarkan oleh Bank Indonesia sebelumnya. Bedanya hanya terletak pada keberadaan Dewan Pengawas Syari'ah dalam struktur organisasi perusahaan (Ali Rama, 2016:7).

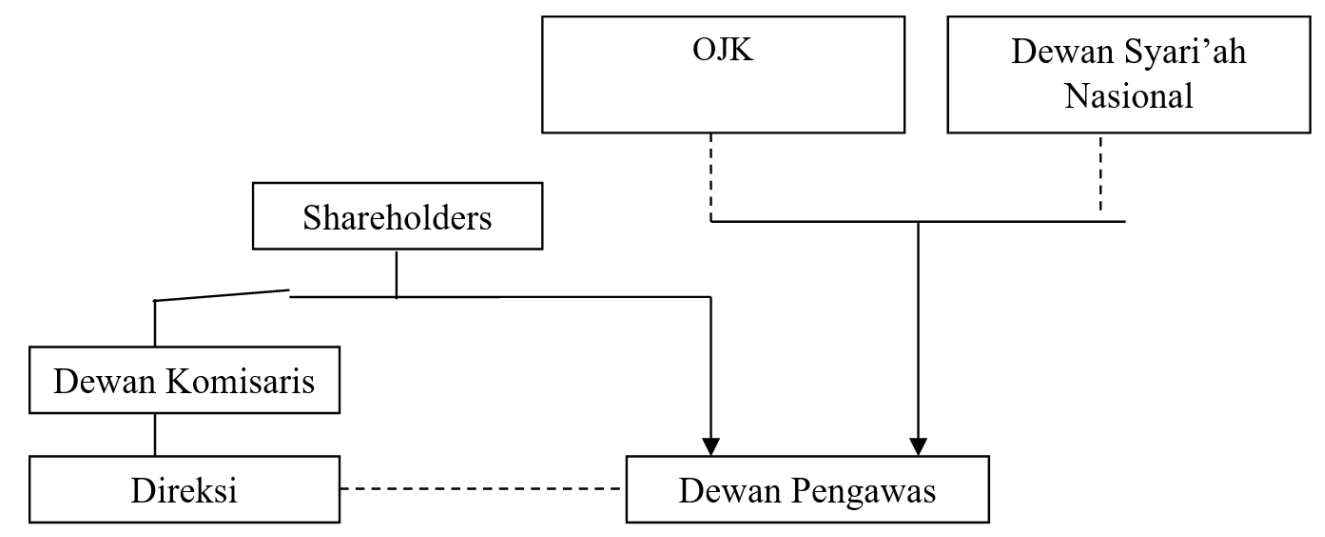

Bagan 1. Struktur organisasi LKS

Struktur organisasi dari sistem tata kelola syari'ah bermakna bagaimana struktur kelembagaan proses pengawasan kepatuhan syari'ah. apakah struktur kelembagaan menganut pendekatan sentralisasi atau independen. Sehingga berdampak pada keberadaan struktur organisasi pengawasan syari'ah pada level nasional dan level perusahaan.

Berdasarkan kerangka regulasi, struktur tata kelola syari'ah bagi perbankan syari'ah di Indonesia manganut 2 (dua) level pengawasan, yaitu pengawasan oleh Dewan Syari'ah Nasional (DSN) pada level nasional dan Dewan Pengawas Syari'ah (DPS) pada level internal perusahaan. Kedua jenis lembaga pengawas syari'ah ini disebut dalam UU No. 21/2008 dan PBI No. 6/24/ $\mathrm{PBI} / 2004$. DSN adalah lembaga bentukan MUI (Majelis Ulama Indonesia) yang bertugas untuk mengkaji, menggali dan merumuskan nilai dan prinsip-prinsip hukum Islam (syariat) dalam bentuk fatwa untuk dijadikan pedoman dalam kegiatan transaksi di lembaga keuangan syari'ah.

Status keorganisasian DSN adalah organisasi non-pemerintah tetapi fatwa yang dikeluarkannya bersifat mengikat bagi industri keuangan syari'ah sebagaimana termaktub dalam Pasal 26 UU No.21/2008 tentang Perbankan Syari'ah. Pada level perusahaan terdapat DPS yang melakukan pengawasanpelaksanaan fatwa DSN tentang prinsip syari'ah. Proses pengangkatan anggota DPS 
merupakan hasil kerjasama antara Bank Indonesia (BI)/Otoritas Jasa Keuangan (OJK) dengan DSN. Dengan demikian, DPS berperan dalam menjembatani hubungan antara BI sebagai organisasi pemerintah dan DSN sebagai organisasi nonpemerintah.

Dengan demikian, Indonesia menganut sistem sentralisasi dan standarisasi fatwa keuangan syari'ah yang level pengawasannya pada industri dilakukan oleh DPS. Hubungan antara DPS dan direksi dalam struktur organisasi perusahaan adalah hubungan koordinasi, yaitu DPS dapat memberikan nasehat dan saran kepada direksi terkait pelaksanaan prinsip syari'ah.

Tugas dari Dewan Pengawas Syari'ah menurut UU No.21/2008 tentang Perbankan Syari'ah adalah untuk memberikan nasehat dan saran kepada direksi serta mengawasi kegiatan agar sesuai dengan prinsip syari' ah. Operasionalisasi dari tugas DPS tersebut selanjutnya yaitu: (i) memastikan dan mengawasi kesesuaian kegiatan operasional bterhadap fatwa yang dikeluarkan oleh DSN; (ii) menilai aspek syari'ah terhadap pedoman operasional, dan produk yang dikeluarkan bank; (iii) memberikan opini dari aspek syari'ah terhadap pelaksanaan operasional bank secara keseluruhan dalam laporan publikasi bank; (iv) mengkaji produk dan jasa baru yang belum ada fatwa untuk dimintakan fatwa kepada DSN; dan (v) menyampaikan laporan hasil pengawasan syari' ah sekurang kurangnya setiap enam (6) bulan kepada Direksi, Komisaris, Dewan Syari'ah Nasional dan Bank Indonesia, OJK.(Ahmad Syaroza, 2008)

Kesemua struktur, tanggung jawab dan fungsi ini ditujukan kepada pemenuhan prinsip syariah oleh LKS dan merupakan suatu yang urgent. Sesuatu LKS yang beroperasional dengan hilah atau trik menyimpan atau mengaburkan transaksi ribawi dapat dihindarkan karena hilah adalah bentuk fraud atau kecurangan. Fraud ini menyebabkan runtuhnya kepercayaan masyarakat terutama umat Islam yang berjumlah mayoritas dan ingin bertransaksi dengan cara yang sesuai syariah dengan menghindari riba, maysir dan ghoror

\section{Kondisi riil Penerapan Prinsip Lembaga Keuangan Syari’ah}

Apakah semua praktik LKS telah sesuai dengan fatwa DSN di lapangan? Agar dikatakan layak secara syariah, LKS harus menselaraskan operasionalnya dirinya sesuai dengan fatwa DSN MUI. Namun, lain dikata, lain realita, ternyata banyak praktek LKS yang bertentangan dengan fatwa DSN MUI sehingga menabrak batas batas syariah.

Untuk membuktikan hal itu, mari kita adakan perbandingan antara fatwa DSN (Dewan syariah Nasional) MUI dengan praktek yang diterapkan di LKS. Semoga perbandingan ini menjadi temuan positif bagi semua kalangan yang peduli dengan perkembangan LKS di negeri kita dan untuk selanjutnya dapat dipergunakan memperbaiki operasional.

Fatwa Pertama: tentang Murabahah Kontemporer. Akad Murabahah adalah satu satu produk LKS yang banyak diminati masyarakat. Karena akad ini menjadi alternatif mudah dan tepat bagi berbagai pembiayaan atau kredit dalam perbankan atau lembaga keuangan konvensional yang tentu sarat dengan riba. Kebanyakan ulama dan juga berbagai lembaga fikih nasional atau internasional, membolehkan akad murabahah kontemporer. Lembaga fikih nasional DSN (Dewan Syariah Nasional) di bawah MUI, juga membolehkan akad murabahah, sebagaimana dituangkan dalam fatwanya no: 04/DSN-MUI/IV/2000. Fatwa DSN ini, menjadi payung dan pedoman bagi perbankan syariah dalam menjalankan akad murabahah.Tapi bagaimana praktek bank syariah terhadap fatwa Murabahah? DSN pada fatwanya No: 04/DSN-MUI/IV/200, tentang Murabahah menyatakan: "Bank membeli barang yang diperlukan nasabah atas nama bank sendiri, dan pembelian ini harus sah dan bebas riba." (Himpunan Fatwa Dewan syariah Nasional MUI, 2008: 24)

LKS manakah yang benar-benar menerapkan ketentuan ini, sehingga barang yang diperjualbelikan benar-benar telah dibeli? Pada prakteknya, perbankan dan LKS syariah, hanya melakukan akad murabahah bila nasabah telah terlebih dahulu melakukan pembelian dan pembayaran sebagian nilai barang (baca: bayar uang muka). Adakah bank yang berani menuliskan pada laporan 
keuangannya bahwa ia pernah memiliki aset dan kemudian menjualnya kembali kepada nasabah? Tentu anda mengetahui bahwa perbankan di negeri kita, baik yang berlabel syariah atau tidak, hanyalah berperan sebagai badan intermediasi.

Artinya, bank hanya berperan dalam pembiayaan, dan bukan membeli barang, untuk kemudian dijual kembali. Karena secara regulasi dan faktanya, bank maupun LKS tidak dibenarkan untuk melakukan praktek perniagaan praktis. Dengan ketentuan ini, bank tidak mungkin bisa membeli yang diperlukan nasabah atas nama bank sendiri. Hasilnya, bank telah melanggar ketentuan DSN MUI di atas secara terang.

Fatwa Kedua, Tentang Akad Mudharabah (Bagi Hasil). Akad Mudharabah adalah akad yang oleh para ulama telah disepakati akan kehalalannya. Karena itu, akad ini dianggap sebagai tulang punggung praktek perbankan syariah. DSN-MUI telah menerbitkan fatwa no: 07/DSNMUI/IV/2000, yang kemudian menjadi pedoman bagi praktek perbankan syariah. Tapi, lagi-lagi, praktek LKS perlu ditinjau ulang.

Pada fatwa dengan nomor tersebut, DSN menyatakan: "LKS (lembaga Keuangan Syariah) sebagai penyedia dana, menanggung semua kerugian akibat dari mudharabah kecuali jika mudharib (nasabah) melakukan kesalahan yang disengaja, lalai, atau menyalahi perjanjian." Pada ketentuan lainnya, DSN kembali menekankan akan hal ini dengan pernyataan: "Penyedia dana menanggung semua kerugian akibat dari mudharabah, dan pengelola tidak boleh menanggung kerugian apapun, kecuali diakibatkan dari kesalahan disengaja, kelalaian, atau pelanggaran kesepakatan."

Praktek LKS sebenarnya di lapangan masih jauh dari apa yang di fatwakan oleh DSN. Andai perbankan syariah maupun LKS benar-benar menerapkan ketentuan ini, niscaya masyarakat berbondong-bondong mengajukan pembiayaan dengan skema mudharabah. Dalam waktu singkat pertumbuhan perbankan syariah akan mengungguli perbankan konvensional. Namun kembali lagi, fakta tidak semanis teori.

Perbankan syariah maupun LKS yang ada belum sungguh-sungguh menerapkan fatwa DSN secara utuh. Sehingga pelaku usaha yang mendapatkan pembiayaan modal dari perbankan syariah, masih diwajibkan mengembalikan modal secara utuh, walaupun ia mengalami kerugian usaha. Terlalu banyak fakta dari nasabah mudharabah bank syariah yang mengalami perlakuan ini.

Fatwa Ketiga, Tentang Gadai Emas, Gadai emas merupakan cara investasi yang marak ditawarkan perbankan syariah akhir-akhir ini. Gadai emas mencuat dan diminati banyak orang sejak harga emas terus membumbung tinggi.

Dewan Syariah Nasioanal melalui fatwanya no: 25/DSN-MUI/III/2002membolehkan praktek ini. Pada fatwa tersebut DSN menyatakan: "Besar biaya pemeliharaan dan penyimpanan marhun (barang gadai) tidak boleh ditentukan berdasarkan jumlah pinjaman." Sementara dalam fatwa DSN No: 26/DSN-MUI/III/2002 yang secara khusus menjelaskan aturan gadai emas, dinyatakan: "Ongkos sebagaimana dimaksud ayat 2 besarnya didasarkan pada pengeluaran yang nyata-nyata diperlukan.

Perbankan syariah atau LKS manakah yang mengindahkan ketentuan ini? Fakta dilapangan membuktikan bahwa LKS yang ada, telah memungut biaya administrasi pemeliharan dan penyimpanan barang gadai sebesar persentase tertentu dari nilai piutang. Jika LKS atau perbankan syariah bersedia menerapkan fatwa di atas, tentunya dalam menentukan biaya pemeliharaan emas yang digadaikan, bank akan menentukan berdasarkan harga Safe Deposit Box (SDB). Akan tetapi, fakta menunjukkan bahwa ongkos penyimpanan yang dibebankan nasabah TIDAK sesuai dengan biaya riil yang dibutuhkan untuk standar penyimpanan dan penjagaan bank, atau melebihi nilai harga SDB untuk penyimpanan emas. Dus, lagi-lagi praktek perbankan/LKS syariah nyata-nyata melanggar fatwa DSN (Muhaamad Arifin Badri, 2012: 33)

Ketidak syariahan bank syariah justru dalam taraf mendasarnya yaitu ketidak sesuaian operasional dengan fatwa DSN, Menerapkan Hilah dengan mengistinbathkan denganhal yang tidak sesuai. Ketidak sesuaian LKS maupun bank syariah ini pada akhirnya diakui oleh direktur 
direktorat perbankan syariah Mulya E. Siregar menyatakan bahwa perbankan syariah belum benar benar menerapkan system syariah. Menurut Mulya tidak ada Bank Syariah yang benar benar syariah, bahkan IDB sekalipun.

Ungkapan Direktur BI ini merupakan sesuatu yang riil bahwa perbankan maupun LKS belum ada yang benar benar berprinsip sesuai syariah walaupun sangat mengejutkan karena segenap peraturan, bahkan dibuat struktur guna pengawasan pun masih belum sepenuhnya sesuai syariah. Menjadi kebutuhan untuk LKS agar dapat hidup dan berkembang dan yang terpenting sesuai dengan syariah.

\section{KESIMPULAN}

Dari hal diatas maka dapat diambil kesimpulan sebagaimana berikut :

a. Penerapan prinsip syariah bagi Lembaga Keuangan Syariah (LKS) maupun perbankan syariah adalah hal yang sangat urgen.

b. Demi mencapai kondisi penerapan syariah tersebut diciptakan struktur pengawasan maupun penerapannya serta dipandu dengan fatwa Dewan Syariah Nasional.

c. Undang-Undang maupun peraturan lain telah mensupport sebagian dari tujuan tersebut namun masih ada regulasi yang belum.

d. Masih terdapat ketidaksesuaian praktik perbankan maupun LKS yang tidak sesuai fatwa DSN atau tidak sesuai syariah dan perlu untuk dibenahi.

e. Terdapat LKS yang melakukan hilah atau trik guna mengambil riba.

\section{DAFTAR PUSTAKA}

Adiwarman A. Karim, 2002, Bank Islam Analisis Fiqih dan Keuangan, Edisi ketiga PT. Raja Grafindo, Jakarta.

Arifin Badri, Muhammad, 2012, Fatwa DSN-MUI Vs Praktek Perbankan Syariah, Majalah Pengusaha Muslim, Yayasan Bina Pengusaha Muslim, Jakarta

Baraba, Achmad. 2010. Prinsip dasar operasional perbankan syariah, Gema Insani. Bandung

Fokus Media, 2011, Kitab Undang-Undang Ekonomi Syariah, Fokus Media, Bandung

Harif Amali Rivai. 2006, Identifikasi Faktor Penentu Keputusan Konsumen Dalam Memilih Jasa Perbankan : Bank Syariah Vs Bank Konvensional, Jurnal Center For Banking Research Universitas Andalas, Padang.

Hassan, dkk., 2013, A Comparative Analysis of Shariah Governance in Islamic Banking Institutions Across Jurisdiction”. Isra Research Paper, No. 50/2013, Kuala Lumpur.

Hudribiq, Mohammed. 1988. Ushul Fiqh. Dar al Fikr. Beirut.

IFSB, 2009, Guiding Principles on Shariah Governance Systems for Institutions Offering, Islamic Financial Sevices, Kuala Lumpur

Isra, 2010, Islamic Financial System: Principles and Operations. Isra Press: Kuala Lumpur

Jannah, Nasyitotul, 2012, Studi Kritis Terhadap Implementasi Akad Murabahah di

Lembaga Keuangan Syariah, Jurnal FAI-Unmuh Semarang, Semarang

Lina Maulidiana, 2011, Penerapan Prinsip-Prinsip Murabahah Dalam Perjanjian Islam (Kajian Operasional Bank Syariah Dalam Modernisasi Hukum), Jurnal Sains Dan Informasi No.7, Fakultas Hukum Universitas Sang Bumi Ruwa Jurai, Bandar Lampung 
Maskanul Hakim, Cecep. 2013. Problem Pengembangan Produk Dalam Bank Syariah. DPNP. Jakarta

MUI, 2008, Kumpulan Fatwa DSN-MUI 2000-2007, Jandiar Press , Jakarta

Rama, Ali, 2014, Analisis Komparatif Model Shariah Governance Lembaga Keuangan Syariah: Studi Kasus Negara ASEAN, Laporan Penelitian Puslitpen UIN Syarif Hidayatullah Jakarta 2014

Rama, Ali, 2015, Analisis Sistem Tata Kelola Syariah Bagi Perbankan Syariah di Indonesia dan Malaysia, Jurnal Bimas Islam Vol 8 No. 1, Dirjen Bimas Islam, Jakarta

Syafii Antoni, Muhammad. 2009. Bank Syariah Dari Teori ke Praktik. Gema Insani. Depok Yogyakarta.

Syakhroza, Akhmad, 2008. Corporate Governance, Sejarah dan Perkembangan, Teori, Model dan Sistem Governance serta Aplikasinya dan pada Perusahaan BUMN, Lembaga nerbitan FE UI, 2008, Jakarta. 